\title{
Más allá de la ideología y de la teología: Protesta social, vida cotidiana y diferencias culturales en los Andes de Jujuy
}

Claudia Lozano B.

\section{RESUMEN}

Durante la pasada década emerge en Argentina una nueva forma de protesta social. La población del campo responde a la insensibilidad de los líderes políticos y sindicales bloqueando las principales carreteras del país e interrumpiendo el transporte de mercaderías. Ante tales circunstancias, el gobierno usualmente envía tropas para prevenir "explosiones sociales" y el "caos político". Mientras el análisis social tradicional considera que la protesta social emerge a partir de las manipulaciones de líderes políticos y religiosos importantes, el análisis social inspirado en la tesis de la vulnerabilidad aprecia la protesta social como una reacción espontánea y desesperada de una población no organizada. En este artículo se recusan ambas maneras de representar el significado de la protesta social por quienes se encuentran envueltos en ella. Argumento que la población trabajadora andina del Noroeste argentino usa los bloqueos de carreteras como una táctica que garantiza la visibilidad de sus demandas en los medios de comunicación. La relación entre población trabajadora andina, representación política y agencia es compleja y no puede ser reducida a la actividad manipuladora de actores políticos o a la reacciones espontáneas de gente viviendo en los márgenes de la sociedad. El análisis de la emergencia de estas múltiples demandas muestra que sus relaciones están caracterizadas por la confrontación y la reciprocidad.

1 Centro de Estudios e Investigaciones Laborales (CEIL) del Consejo Nacional de Investigaciones Científicas. Email: clozan@aol.com

2 Mosconi es una localidad cuya actividad económica se basaba en la extracción y el procesamiento de petróleo realizada por la empresa estatal YPF, privatizada en la década anterior.

\begin{abstract}
During the last decade a new social protest emerged in Argentina. The population of the country side react to the insensibility of political and union leaders by interrupting the transportation of goods in the main highways of the country. In such circunstances, government usually sends military troops in order to prevent "social explosions" and "political chaos". Where as traditional social analysis considers that the social protest emerge from the manipulative activities of powerful political and religious leaders over the poor population, social analysis inspired in the vulnerability thesis sees the social protest as a desperate and spontaneous reaction of unorganized population. In this paper I will challenge both ways of representing the meaning of social protest for those who are involve in it. I argue that the andean working population of the argentinean Northwest uses "highway shortages" as a tactic that warrants the "mediatic visibility" of their demands. The relationship between the andean working population, political representation and agency is a complex one and cannot be reduced to the manipulative activity of political actors or to the spontaneous reactions of people living in the margins of society. The analysis of the emergence of the multiple demands of the population shows that their relationship are characterized by confrontation and reciprocity.
\end{abstract}

\section{Introducción}

Durante mayo de 2000 el Noroeste argentino fue nuevamente escenario de una protesta popular. Esta se inició en la provincia de Salta con un "corte de ruta" realizado por los pobladores de la localidad de Mosconi. ${ }^{2}$ Cerca de 300 trabajadores interrumpieron el tráfico en la Ruta Nacional $\mathrm{N}^{\circ} 34$ y durante 12 días demandaron la continuidad del pago de sus salarios y la generación de puestos de trabajo 
con apoyo estatal. La protesta acabó en un enfrentamiento entre dos ciudades del interior de la provincia, y gendarmería. Durante siete horas la gendarmería nacional (700 efectivos) dio batalla frente a 300 desocupados que rápidamente se armaron de palos y piedras para dispersar a los gendarmes. Estos últimos fueron apoyados por 2.000 pobladores de Mosconi, quienes organizaron una procesión por la ciudad con la imagen de la Virgen María que adoraban en la iglesia local. A ellos se sumó una procesión de 10.000 personas que se acercó desde la ciudad vecina de Tartagal, transportando también una imagen de la Virgen María de su iglesia, para apoyar a los manifestantes. Dado el terror desatado por los enfrentamientos, la Iglesia intervino para iniciar negociaciones entre los pobladores y el gobierno. Finalmente, funcionarios de la delegación gubernamental, reconocieron la legitimidad de las demandas y que "tal vez fallamos en no haber venido antes" (Clarín 13/05/2000: 1, 3-14, La Nación 13/05/2000: 1, 5-9, La Nación 14/05/ 2000: 1, 12-15).

Desde la apertura democrática ocurrida en 1983, el Noroeste argentino (NOA) fue escenario de múltiples formas de protesta social frente a la insensibilidad social de funcionarios gubernamentales e internacionales. Las privatizaciones y la apertura económica transformaron las formas de organización del trabajo en Argentina. ${ }^{3}$ Estas transformaciones implicaron despidos masivos del personal empleado en la industria estatal y privada en diversas localidades de las provincias de Salta y de Jujuy. Frente a la nueva situación de desocupación, la población local respondió ocupándose en actividades por cuenta propia y eventualmente participando de los proyectos de asistencia social propuestos por organismos estatales y agencias no gubernamentales. Cuando las actividades por cuenta propia no resultaron adecuadas para proveer a la subsistencia familiar, los trabajadores despedidos interrumpieron el tránsito de las rutas nacionales con el objetivo de hacer visibles sus demandas de trabajo y de cobertura social. ${ }^{4}$ Asimismo, hubo "marchas del silencio" encabezadas por los jóvenes en la ciudad de Catamarca.

3 Conforme a Murmis y Feldman (1996: 197-198) “... la reestructuración económica ha sido muy intensa, pero la perspectiva incluye transformaciones en marcha o anunciadas de importante impacto en el empleo, en particular en amplias regiones del interior del país. Tengamos presente, por ejemplo, el ajuste y la reestructuración del sector público en las provincias y el impacto de los avances del MERCOSUR. De hecho, este último aspecto se conecta con el avance de la apertura
Estos jóvenes se manifestaron contra la impunidad frente a crímenes aberrantes perpetrados contra jóvenes, a la vez que demandaron una justicia independiente del poder político. Hubo además movilizaciones gremiales organizadas por dirigentes políticos y sindicales que buscaban hacer oír sus demandas respecto de la continuidad del pago de los salarios pactados en los contratos de trabajo. Estas protestas pusieron de manifiesto oposiciones frente a las medidas económicas de ajuste y de privatizaciones indiscriminadas, y frente a la impunidad imperante en la última década.

En los relatos de la prensa, estas manifestaciones fueron vistas como parte de una oposición no institucionalizada a través del sistema político de representaciones. Dado el consenso generalizado existente respecto de la legitimidad de las demandas elevadas en las protestas, una pauta habitual de resolución de ellas ha sido la intervención de la Iglesia Católica. Tanto la prensa como la Iglesia desde hace dos décadas emergen como los interlocutores válidos entre una oposición no representada en el parlamento, y las fuerzas políticas y económicas, vistas como especialmente insensibles frente a las necesidades materiales y a las demandas de justicia de la población.

Resulta curioso que, aún cuando la población del NOA emerge en la escena pública confrontando al gobierno con los efectos problemáticos de las medidas de política económica, los discursos políticos, mediáticos y religiosos identifican a la población con el estereotipo del "pobre" o del "marginal" desconectado del resto de la sociedad: personas perpetuamente desocupadas, sin educación, cuyos lazos familiares son inestables y cuya ideología se caracteriza por la ausencia de valores sociales y culturales. Estas personas marginadas estarían sometidas y serían victimizadas por poderes políticos despóticos, cuyo soporte institucional es un liderazgo político corrupto, que utiliza la ignorancia y los votos de las masas pobres y marginadas del sistema social. ${ }^{5}$

externa y la necesaria reestructuración productiva y económica que conlleva.

4 Los "cortes de ruta" fueron documentados por la prensa escrita y televisiva. La prensa es un dispositivo social frente al cual los funcionarios muestran sensibilidad.

5 Declaraciones de la Iglesia Católica durante el conflicto en la provincia de Salta (La Nación 14/05/2000: 1 y 21 ). 
Esta visión de las relaciones entre liderazgo caudillista ${ }^{6}$-clientelar, necesidades materiales de la población y poder político estatal, presentes también en la historiografía tradicional, es algo reconocido y criticado tanto por la memoria popular como por una nueva historiografía. En lugar de enfatizar la desconexión, la marginalidad, el sometimiento y la victimización, éstas subrayan las obligaciones mutuas que caracterizan a las relaciones entre los funcionarios del Estado-nación y la población local. En este contexto explicativo, la protesta, en lugar de constituir una respuesta descontrolada frente a la carencia y a la marginalidad, conforme se desprende de la interpretación de funcionarios, sacerdotes y periodistas, responde a una lógica de la articulación de respuestas basada en la gestión de espacios públicos de negociación política. En una sociedad en la cual este tipo de negociación se restringe a la participación de los miembros de las "cúpulas" que popularizan sus ideas a través de los medios, la protesta social manifiesta en los cortes de ruta no puede considerarse como parte del espontaneísmo de la clase trabajadora, sino que se relaciona con una conceptualización de la distancia y del espacio social, que incorpora el efecto mediático a las prácticas cotidianas de visibilidad. A través de los medios, la población reclamó el cumplimiento de las promesas electorales y de los deberes del funcionario público respecto a la implementación de políticas de reactivación de la producción y del consumo, así como de la extensión de una cobertura social básica?

Los pobladores no son ajenos al liderazgo político caudillista-clientelar propuesto por la élite. El protagonismo campesino, en las "montoneras" y en las guerras "gauchas", así como el protagonismo campesino-indígena en los levantamientos por la propiedad de la tierra durante el siglo XIX, son parte de esta modalidad particular a partir de la cual se construyen los lazos con la autoridad política. Esta forma de relación con la autoridad local, no se caracteriza por la sumisión ciega y la victimización. ni por el espontaneísmo, sino por la reciprocidad y el clientelismo. A través de relaciones de reciprocidad y de clientelismo la población rural negocia sus demandas comunes con las autoridades. Estas negociaciones se caracterizan por una autonomía relativa de las instituciones de representación ${ }^{8}$, y por la necesidad de generar visibilidad respecto de sus demandas.

En este artículo voy a mostrar, a través del análisis de la gestación de las demandas contemporáneas de la población indígena y trabajadora de la Quebrada de Humahuaca, el carácter irreductible de las relaciones con el poder político y económico institucionalizado. Desde la perspectiva de los pobladores, los derechos territoriales de los indígenas y sociales del trabajador son inseparables del respeto por las costumbres de "estilo" y de la experiencia de la organización de la clase obrera. Las convenciones de "estilo" constituyen un conjunto de conocimientos étnicos implícitos en las prácticas agrícolas y ganaderas respecto de las relaciones de reciprocidad existentes entre los seres humanos, la tierra y los espíritus del paisaje que viven dentro de ella. A diferencia de éstas, el reconocimiento de los derechos políticos y sociales del trabajador remiten a la representación política de la clase obrera, vinculadas con el voto secreto y universal, así como a la representación y a la movilización sindical que garantizó el acceso al salario justo, a la propiedad y a los servicios sociales básicos (James 1990: 28-

6 Para una revisión crítica del concepto de caudillismo ver Goldman y Salvatore (1998). Especialmente la introducción de los compiladores ofrece una revisión de los variados significados que la historiografía otorgó a las relaciones caudillistas.

7 Contrariamente a esta postura relevada durante las protestas ocurridas en Humahuaca, Jujuy, en 1997, los funcionarios políticos asocian la protesta social al riesgo de un "estallido social" generalizado, creciente y descontrolado al que el Estado debe dar "contención" para que evitar el caos. Asimismo en los análisis sociológicos el "estallido" es asociado a la debilidad o a la crisis de la acción colectiva: "...los sistemas de acción colectiva están pasando por un momento de inflexión histórica en la región, cuya focalización en demandas puntuales contras-

ta con el proceso de concentración creciente de las decisiones en las élites de poder internacionalizado. Los movimientos de presión local alternan cada vez más con las acciones espontáneas y semiorganizadas de "explosión social" (el encomillado es mío) (Martucelli y Svampa 1997: 43,44). En el contexto explicativo de la concentración del poder social y de la explosión social, las acciones colectivas pueden ser interpretadas como reacciones de la víctima. Pero dado el carácter contestatario de toda actividad social, es necesario contextualizar las actividades y los pensamientos de los actores en los marcos de significado elaborados por ellos mismos para dar cuenta de todas las posiciones en juego.

8 De la Fuente (1999: 293), Paz (1998: 343 y 344). 
Sin embargo, las modalidades de intervención del Estado-nación y de la Iglesia Católica, muy asociada al poder político en Argentina, tienen que ver también con las formas en las cuales sus agentes conceptualizan el poder social. Estas conceptualizaciones son articuladas en discursos sobre las necesidades básicas de la población y la deuda de la nación con los indígenas y con los trabajadores. Pero también operan con arreglo a estrategias de reclutamiento que responden a una lógica de la obtención del voto, del control de cargos y del presupuesto público. En el contexto de la transnacionalización de la economía y del ajuste del presupuesto estatal, las políticas sociales focales fomentadas tanto por el Estado-nación como por una organización no gubernamental (ONG) católica en la región, en lugar de garantizar el bienestar tienden a reforzar mecanismos de ascenso social individuales basados en niveles crecientes de educación formal y en el control de los cargos públicos, prácticas características de las redes políticas clientelares. Asimismo, los agentes políticos y eclesiales han conectado la protesta popular con el poder social y la imposición.

\section{Etnicidad, clase y reconocimiento}

En efecto, la etnografía resulta reveladora respecto de los avances de la historiografía cuando se trata de reconstruir la visión de los actores involucrados en los procesos de negociación de demandas. En

9 El voto secreto existe en Argentina desde 1910. Recién con el advenimiento del peronismo en 1952 los pobladores ejercieron su derecho al voto secreto, libre de coacciones económicas. Anteriormente existía un sistema de clientelas por el cual los indígenas eran obligados a votar por los candidatos propuestos por los ingenios de la región, habitualmente contratistas de mano de obra indígena. Rutledge muestra que la política de reforma agraria y social del peronismo, si bien tuvo efectos reformadores y generó límites a la explotación del trabajo indígena, de todos modos la fuerza inicial de las reformas se vio afectada durante la etapa de implementación (Rutledge 1987: 192 y 193). Recién en 1994 fue sancionada la reforma constitucional que reconoció el derecho inalienable de las comunidades indígenas al usufructo y a la propiedad de la tierra.

10 En la actualidad una nueva generación de antropólogos sociales, etnohistoriadores y geógrafos están menos preocupados por la autenticidad y la subordinación de las formas culturales existentes en la Puna y en la Quebrada argentinas (Isla 1992) aunque sí cuestionan su continuidad con las culturas quechuas y aymaras y con ello el carácter andino de la cultura local. Si bien dicha continuidad no ha sido demostrada (en parte por la ausencia de estudios comparados detallados), como sugiere estos procesos emergen diferencias culturales básicas que son las que dan lugar a la confrontación social. En la región de la Quebrada de Humahuaca y de la Puna de Jujuy es visible la desconfianza y el rechazo que los pobladores muestran frente a discursos partidistas de representación de los "pobres" o de los coyas que proponen salir en busca de las raíces auténticamente "indígenas", restituir la comunidad coya e implantar una economía y una política indígena independientes del Estado-nación. La distancia crítica frente a formas de representación de la autoridad organizadas y unificadas está relacionada a la memoria y a la experiencia histórica de la población de los Andes (Harris y BouysseCassagne 1988: 247, Nash 1985: 115 y 116, Platt 1988: 48). ${ }^{10}$ Las sugerencias de una nueva historiografía y de una nueva antropología respecto del estudio de formas no colectivas y no convencionales de resistencia indígena, resultan reveladoras cuando se trata de explicar la relación entre protesta social y poder político y económico. En lugar de privilegiar el estudio de las rebeliones y el carácter resistente y unívoco de las culturas indígenas, campesinas u obreras frente a la transnacionalización de las economías voy a mostrar que en el contexto de estos procesos, la protesta pone de manifiesto el carácter fragmentario de la resistencia, de la cultura y de la identidad social en los Andes.

Ni la etnicidad, ni la clase son estados acabados, sino que consisten en relaciones sociales concretas en las cuales un conjunto de diferencias adquieren

Platt en su estudio sobre los migrantes mineros en Bolivia, los migrantes campesinos y mineros argentinos comparten con los migrantes bolivianos "... representaciones respecto de la tierra como una fuente de riquezas (tanto agrícola como mineral). [...].Estas representaciones identifican a una cultura popular andina cuyas manifestaciones individuales son múltiples..." (Platt 1988: 48). En Argentina como en Bolivia mientras Pacha representa a la "Tierra" y al "Cerro" como fuente de riquezas, Pacha es también el "Tío", dueño de los minerales ubicados en las profundidades del cerro a quienes hay que celebrar para garantizar la fertilidad y la prosperidad de la vida en la tierra. Es la persistencia de este ideario religioso y de las prácticas rituales asociadas a él, aquello que nos permite mostrar la existencia de continuidades culturales entre los habitantes de los Andes argentinos y bolivianos. En este sentido, Harris muestra que los aymaras aceptaron el ideario religioso cristiano pero adaptándolo a sus las propias visiones del mundo (Harris y Bouysse-Cassagne 1988). Nash sugiere que dicha adaptación no se produce por sustición, sino que es un efecto de contextualización de discursos aparentemente contradictorios. Es en los contextos pragmáticos específicos, donde estos discursos adquieren un significado concreto (Nash 1985: 116). 
significados. La etnicidad se caracteriza por la incorporación asimétrica de agrupamientos estructuralmente disímiles a una misma economía política. Esta forma de incorporación de las diferencias y de la identidad de las personas implica que las concepciones sobre la identidad étnica de los grupos subordinados y de los grupos dominantes pueden ser divergentes (Comaroff y Comaroff 1992: 54)." En la Puna y la Quebrada de Humahuaca, la cultura local, visible en las "costumbres de estilo", no es el residuo de una tradición prehispánica, ${ }^{12}$ sino que son justamente los procesos contemporáneos de la globalización los que otorgan significado a las diferencias culturales como algo que irremediablemente conlleva a la marginalidad, a la pobreza y/o a la hibridación los que demandan de una explicación. Estos significados son coproducidos en las instituciones (la familia, la Iglesia, la escuela, el partido, la prensa), las cuales generan y sostienen jerarquías étnicas e ideologías de clase como las que refiere Comaroff y Comaroff (1992). Sin embargo, la formación de identidades y subjetividades étnicas, de clase o incluso la identidad del sujeto híbrido, no deben con-

11 En su interesante discusión sobre la relación existente entre etnicidad y clase social, Comaroff y Comaroff (1992) sugieren que la emergencia de agrupamientos étnicos y de una conciencia étnica son producto de "...procesos históricos que estructuran relaciones de desigualdad entre entidades sociales discretas, en otras palabras, ellas consisten en los correlatos culturales de un modo de articulación específico entre agrupamientos, en el cual uno de los grupos extiende su dominación sobre el otro a través de formas coercitivas, violentas y de otras formas; sitúa a los últimos en una posición asociada a la división del trabajo inclusiva: y al quitarles el control de los medios de producción, regulan los términos en los cuales se les extrae valor. Esto lleva a que el grupo dominante constituya tanto a sí mismo como al grupo subordinado como clases. Definir las diferencias y las similitudes existentes entre las personas en términos de la etnicidad, implica entonces, que la identidad imputada al grupo subordinado desde fuera puede no coincidir con la experiencia subjetiva de la identidad. En este contexto, el "otro" es, entonces, una contraimagen de la propia identidad social, no una descripción empírica de una población particular. Finalmente los autores destacan que la proporción en la cual las identidades étnicas están ancladas en realidades culturales previas es variable. Especialmente cuando las clases subordinadas se componen de personas de diversos orígenes, la substancia de dichas identidades es concebida tanto desde dentro como desde fuera del grupo. En este contexto resulta inevitable la existencia de un bricolage producido en el propio proceso histórico que produjo su subordinación (Comaroff y Comaroff 1992: 55-57). siderarse como un proceso transhistórico sino que, dado su carácter contextual y subjetivo, estas son simultáneamente "contestadas" (imputadas, rechazadas, reevaluadas, reorientadas, etc.) (James 1998: 4). No se trata de sostener una visión utópica sobre las clases trabajadoras o las sociedades indígenas, sino de una cuestión de responsabilidad respecto de nuestras intervenciones, dado que las mismas suponen reconocer el significado que los involucrados le otorgan a sus prácticas (Harvey 1997: 75).

\section{La intervención de la Misión Claretiana en Humahuaca}

Desde hace más de tres décadas los sacerdotes de la misión Claretiana instalados en la parroquia de Humahuaca ${ }^{13}$ han denunciado las complicidades existentes entre funcionarios de la administración provincial y el empresariado privado local, respecto de su propio enriquecimiento personal. El enriquecimiento repentino y calculado de funcionarios y empresarios estaba ligado al endeudamiento constante del Estado provincial y a la disminución de los presupuestos domésticos de los hogares

12 En la actualidad en el seno del grupo de estudios interdisciplinarios sobre la región de La Puna y de La Quebrada (PUQUE) estamos debatiendo la adecuación de englobar a los habitantes y a las diferencias culturales que los caracterizan como parte de una cultura coya. Teniendo en cuenta el rechazo generalizado de los propios habitantes a incluirse dentro de la categoría coyas, categoría utilizada para designar procesos de subordinación étnica y desvalorización cultural, en este trabajo voy a referime a las diferencias culturales en términos de "las costumbres de estilo" ampliamente compartidas por los pobladores tanto de La Puna como de la Quebrada de Humahuaca. ¿El rechazo a identificarse como cova habla de la disolución de la identidad étnica, o más bien refiere at rechazo frente a la subordinación de quienes son vistos como étnicamente diferentes? Es importante destacar que el significado de las diterencias, expresadas en términos étnicos, es disputado y por lo tanto tiene vigencia como forma de entender las diferencias culturales. Esto se hace visible en el debate existente en las Iglesias (Católica y Bautista) sobre el significado de las "costumbres de estilo". Las mismas son rechazadas por paganas por sacerdotes católicos y pastores bautistas. Asimismo la auténtica cultura y religión de los coyas es impartida por los sacerdotes y sus agentes en las lecciones de catecismo. Frente a ello los feligreses continúan hablando de las "prácticas de estilo" como algo propio.

13 Realicé mi trabajo de campo etnográfico en tres estadías de cuatro meses en 1993, 1995 y 1997, respectivamente. Durante mis estadías recolecté entrevistas grabadas a 115 habitantes de la ciudad y los habitantes de localidades rurales, a sacerdotes y políticos locales, asistí a charlas informales y registré comentarios en numerosos encuentros vecinales, eclesiales y en rituales religiosos. 
humahuaqueños amenazados por la baja persistente de los salarios y por la desocupación. ${ }^{14}$ Los sacerdotes no sólo se sumaron a las protestas organizadas por los sindicatos mineros y estatales, sino que ellos mismos participaron de su organización y sostenimiento, de cortes de ruta y marchas hacia la capital de la provincia y publicaron numerosos artículos de denuncia de despidos masivos, violación de los derechos de los trabajadores y utilización de fondos destinados a programas sociales en campañas electorales. Como resultado de estas actividades los sacerdotes de la Misión Claretiana se convirtieron a sí mismos y fueron convertidos por los periodistas, en los líderes y representantes legítimos de los indígenas pobres del Noroeste argentino (Revista Animadores 1995, $\mathrm{N}^{\circ}$ 176: 1).

$\mathrm{El}$ alineamiento de los misioneros con los intereses de los indígenas llevó a los sacerdotes a agregar a las organizaciones caritativas (Liga de Madres, Legión de María, Cofradías de los Santos Patrones, Cursillistas de Cristiandad) las actividades de una organización no gubernamental (ONG), Organización Claretiana para el Desarrollo (OCLADE), dedicada a la implementación de proyectos de desarrollo local. Desde comienzos de 1980, OCLADE se transformó en la institución más ágil y más controvertida de la provincia. En 1983 la ONG comenzó a canalizar fondos destinados a fomentar actividades empresariales y de capacitación de los pequeños productores a través del apoyo financiero para la formulación de proyectos y ejecución de obras de infraestructura. De este modo, los misioneros claretianos están abocados al trabajo de concientización de las necesidades materiales de los indígenas pobres, e intervienen activamente en la transformación de sus condiciones materiales de vida y en la revalorización de su cultura y de sus

14 En 1991 vivían en el Departamento de Humahuaca 18.183 personas, de las cuales $8968(49 \%)$ eran varones y 9215 $(51 \%)$ eran mujeres. En 1991 el total de personas en edad de trabajar (14-60) eran 10.181 y de ellos 5.488 constituían la población económicamente activa (PEA). De las 5.488 que integraban la PEA. el 52\% declararon haber trabajado en la última semana y son considerados "ocupados"; el 3,7\% declararon no hacer trabajado en la última semana y conforman la población "desocupada", mientas que el resto son considerados inactivos. Entre los ocupados (5.291), el 55\% eran obreros o empleados: $21,96 \%$ eran empleados estatales; $28,70 \%$ empleados del sector privado; $4.6 \%$ empleados en el servicio doméstico: $4 \%$ trabajadores por cuenta propia; $1 \%$ como patrones; $16 \%$ trabajador familiar sin remuneración fija. Sin embargo, el dato más significativo es que de $\mathbf{5 . 2 9 1}$ personas prácticas religiosas sincréticas (Revista Animadores 1995: $\mathrm{N}^{\mathrm{o}}$ 184: 8 ).

Sin embargo, cuanto más preocupados están los sacerdotes por la concientización respecto de las necesidades materiales de los pobres, los pobladores de Humahuaca cuestionan más el énfasis de los sacerdotes en la protesta y en la intervención social y reclamaban una mayor dedicación a las cuestiones del espíritu: ¿Por qué los agricultores, obreros, desempleados o cuenta propias rechazan el mensaje de lucha por la transformación de las condiciones materiales en las cuáles transcurren sus vidas? ¿Cómo resuelven ellos las relaciones problemáticas existentes entre experiencia, demandas y representación social?

Hasta la instalación de la ONG católica y la expansión de grupos de base ocurridas hace dos décadas, las organizaciones eclesiales de Humahuaca, estaban lideradas por mujeres, en su mayoría maestras, que pertenecían a las familias que "más tienen" ${ }^{15}$ de la ciudad. Estas familias controlaban los puestos de trabajo de la administración municipal, provincial y nacional: escuelas, hospital, Registro Civil, etc. Tenían contacto con la gente del campo a través de las redes de parentesco y de compadrazgo que les garantizaban contar con mano de obra para sus casas y para los trabajos agrícolas y de maestranza en las instituciones. Desde la instalación de OCLADE, la Iglesia se pobló de parejas de profesionales universitarios que venían a vivir y a trabajar a la región para "estar con la gente". Asimismo, la nueva política eclesial destinada a promover la organización y la satisfacción de las necesidades de los más pobres implicó la transformación de la composición del grupo de dirigentes eclesiales de la Parroquia de Humahuaca que propuso un nuevo debate.

consideradas ocupadas, solamente $2.440(34 \%)$ tenían un trabajo estable con prestaciones sociales: seguro de salud y previsión social. El resto $66 \%$ lo hacía fuera de los convenios legales (INDEC: Censo 91, Jujuy, Serie B N 10, 1994: 61 y Censo, 1991: 45, 49, 54).

15 La ciudad de Humahuaca tiene tres zonas claramente diferenciadas. El centro de la ciudad donde residen, autoridades, comerciantes y funcionarios de la administración (los que "más tienen", "los patrones" o "la autoridá" en el lenguaje popular), los barrios periféricos donde residen los funcionarios empleados en los estratos inferiores de la administración y artesanos ("gente de trabajo") y los barrios altos donde residen los migrantes desocupados que llegaron a la ciudad en la última década ("gente de trabajo" o"los humildes) (Lozano 1999a: 103-108). 


\section{El debate sobre la Promoción Humana y sobre la Caridad}

La nueva política eclesial no llegó a Humahuaca y se encontró con una situación de vacío, sino que se vio enfrentada a cuestionamientos y los sacerdotes tuvieron que argumentar y demostrar la eficiencia y la eficacia de sus propuestas frente a las damas católicas que ostentaban un manejo de "lo religioso". En este contexto, hacer visible la experiencia de la clase trabajadora y de la etnicidad no constituía una labor fácil, sino que este ejercicio de representación se enmarcaba en luchas históricas por el reconocimiento social y político, donde los contrincantes o rivales tenían posiciones divergentes entre sí respecto a la cultura y al tratamiento de las necesidades básicas de la población.

María Eugenia tiene 50 años, es líder religiosa, "Animadora de la Palabra" y "Animadora de la Promoción Humana", desde 1980 y 1987, respectivamente. Como muchas mujeres de su edad, ella y su esposo se trasladaron de una localidad rural hacia la ciudad de Humahuaca, donde su esposo había conseguido un puesto de Asistente Sanitario en el Hospital y reunía ingresos mensuales de $\$ 500$. Ambos colaboraban con su madre en los trabajos agrícolas y ganaderos y a cambio recibían frutas, verduras y carne del campo. Alquilan una casa modesta de tres cuartos en un barrio periférico donde viven con sus dos hijas.

"Yo siempre he sido de participar porque los cristianos tenemos que ayudar y colaborar de eso se trata la caridad. ¿No es cierto?" (entrevista a María Eugenia, Humahuaca, 1993).

María Eugenia representaba a las mujeres que migraron hacia la ciudad pero que mantienen lazos con el trabajo agrícola y ganadero a través de la red de parentesco. En la ciudad se integró a las actividades habituales de asistencia y de organización de fiestas patronales y procesiones. Desde la llegada de los sacerdotes claretianos se vio confrontada con un staff de profesionales universitarios rentados que impulsaban transformaciones de las actividades tradicionales de iglesia. En este contexto manifestaba sus dudas acerca de la apertura de la Iglesia hacia la cultura Coya y hacia los "pobres":

"Lo cultural también se ha perdido porque ellos lo han quitado (se refiere a los sacerdotes). Pero aho- ra lo están queriendo rescatar lo perdido. Cuando ellos llegaron en el '68 comenzaron a quitar las imágenes, a quitar las cha'lladas de la tierra, a quitar las ofrendas de Todosantos. Porque decian que como es eso que van a estar velando el pan ahí. Yo le decía al cura, para mí, dentro de lo religioso está bien, porque se reza se pide por las "almas", y se va en grupos rezando todo el día. Y más que nada después que levantan las ofrendas se dedican a tomar todas las bebidas que ponen. Y ellos decian que eso era lo pagano. Pero si, yo le decía Padre, pero Padresito si se va a rezar se pide por las "almas" es bueno, mirándolo de lo religioso. Y si miramos del amor de la caridad, eso es caritativo, porque se reúne toda la gente de donde sea. Porque ahi no se ve de donde usted es. Se ponen asi a la vuelta, comienza el reparto de las ofrendas y todos reciben. Uno de cada cosa. Porque ponen, por ejemplo, pan salado, dulce, rosquete, empanadillas y todos van recibiendo por igual. Y eso es lo que nosotros vemos como caritativo, eso es lo que nosotros no vemos como pagano, si eso se lo regala" (entrevista a María Eugenia, Humahuaca, 1993).

Ella otorga a la caridad un significado alternativo al dominante en el medio católico. En el contexto de los rituales que caracterizan a la cultura local la "caridad" no refiere a relaciones basadas en la desigualdad, la gente que "más tiene" le da a los que "menos tienen", sino que la caridad refiere a una comunidad religiosa en la cual las diferencias no hacen a las personas ni objeto de beneficencia ni de discriminación, sino que los católicos comparten lo que producen entre sí. Desde su punto de vista, los sacerdotes y los profesionales introducen concepciones "paganas" que en lugar de recrear la comunidad de creencia, ritos y prácticas, la rompen:

"Se perdió la devoción y anoche justamente cuando estuvimos en la reunión yo le decía al Padre, porque ellos decían con respecto a la familia de que tienen que salir lo religioso desde el hogar si resulta que en el hogar ahora hace falta mucha espiritualidad. Creo que eso desde la Iglesia se está perdiendo. Para mi es que desde la Iglesia nos estamos yendo por las ramas. Nos estamos yendo mucho a lo material y en lo espiritual lo estamos dejando de lado. Para mí es eso. Podés llevar el pan hoy, pero si vos no vas llevándole para mañana y para los días siguientes no tiene sentido. Si vos le hablás a la luz de la Palabra, le hacés ver lo que Dios quiere, de cada uno y cómo cada uno debe 
salir a buscar el alimento es distinto"(entrevista a María Eugenia, Humahuaca, 1993).

La cultura local, basada en la existencia de redes de parentesco y de vecindad, provee a María Eugenia de un contradiscurso potente frente a los sacerdotes y a los profesionales. Su esposo salió a buscar trabajo y consiguió un empleo fuera de la localidad y ella, a través de su trabajo honorario, se encarga de redistribuir recursos domésticos entre su hogar y el de su madre y recursos comunitarios entre la ciudad y el campo. Ella y su esposo viven y trabajan en la ciudad de Humahuaca pero mantienen lazos estrechos con el campo. Su esposo "ayuda" a su madre con los trabajos agrícolas y ganaderos y ella con ropa y mercaderías de la ciudad (azúcar, aceite, sal, etc.), y su madre los provee de verduras y carne. Asimismo asisten a las celebraciones familiares y vecinales de Uquía y llevan "proyectos", ropa y mercaderías para los vecinos de la localidad.

A diferencia de María Eugenia que es una animadora honoraria, Felipe es un promotor rentado de OCLADE e inspector municipal. Ambas actividades le permiten reunir ingresos de $\$ 500$ con los que mantiene a su esposa, dos hijos y a su suegra. Vive en una casa de cuatro ambientes en construcción en el barrio alto de la ciudad. Su esposa se ocupa de los trabajos del hogar y sus hijos asisten a la escuela. Felipe es hijo de una mujer que fue abandonada por su compañero y que trabajó vendiendo verduras en las calles de La Quiaca. Asistió al colegio primario y luego comenzó a trabajar en la Mina Pirquitas.

"Aquí hay una religión medio teórica de rezar y nada más esa frase que decía 'salva tu alma'. Una cosa es el alma, la parte también fisica, social y espiritual, el hombre integral. Por el año 1970, '71 yo trabajaba en Pirquitas, era un obrero más, y me dediqué a trabajar allá cuando llegaron los sacerdotes, el Padre Nicolás. Influyó en mi madre esa religiosidad popular que uno veía, a veces la he visto llorar a mi madre, llorar a ese Dios lejano. Creo que eso si marcó mucho en mi vida. Ella dejaba todo a Dios. Por la injusticia que vía, a veces mi madre tenía gente que no le sabía pagar. A mi desde esa época el tema de la justicia, ahí empezó a pesar esa cosa de la justicia. Eso me marcó de chiquito, después trabajé en Pirquitas (una empresa minera) y comencé a acercarme al sindicalismo. En el año '75 yo rearmo el sindicato y la empresa, fija- te, me nombra encargado del tema de viviendas, yo peleaba el tema de viviendas a muerte. Me hicieron un desafio: "si tanto te importa la vivienda anda a ver que se puede hacer". En el '75, en el gobierno del Ingeniero Snopeck había robos que eran los mismos contratistas. Entonces un día me dicen que se han perdido dos radios grandes y todo el personal tiene que ir a la policía. La policía comienza a extorsionar a los compañeros, con un cigarrillo a quemarles el estómago. Eran los mismos tipos de arriba los que robaban. En el '76 nos barren a todos..."16 (entrevista a Felipe, Humahuaca, 1993).

Felipe representa también a los migrantes, pero, a diferencia del caso de María Eugenia, su experiencia y sus condiciones de reproducción no lo asociaban a la agricultura y a las relaciones de reciprocidad, sino al comercio, a la industria y a la vida en la ciudad caracterizadas por relaciones de explotación. El discurso peronista que asociaba la participación política y sindical a las demandas de justicia social --igualdad-- de la clase trabajadora le permitió establecer un puente semántico entre su demanda de reconocimiento de los derechos de los trabajadores y el discurso de la promoción de las demandas de los indígenas desocupados. Felipe fue encarcelado después del Golpe militar de 1976 y los sacerdotes hicieron gestiones frente a las autoridades provinciales para conseguir su libertad. Una vez liberado, los sacerdotes consiguieron que la administración provincial le otorgara un cargo de Promotor Sanitario del Servicio de Atención Primaria de la Salud. Desde entonces realiza cursos de capacitación para promotores sociales y colabora con los sacerdotes y los profesionales en las actividades que ellos proponen.

"Yo hasta esa época no tenía un concepto de un médico un cura que laburen (trabajen) así. Ese estatus, el médico del hospital, que tenés que hacer turno, qué se yo. Ellos salian al campo y se veía como se trabajaba. Hacíamos tres rondas e ibamos

\footnotetext{
16 El 24 de Marzo de 1976 es la fecha de inicio de la última dictadura militar que se prolongó hasta 1983. Durante este período, empresarios y políticos que apoyaron el golpe militar, colaboraron en la disolución del activismo político presente en los sindicatos, en las minas y en los ingenios a través de la denuncia y la entrega de su personal a las fuerzas militares encargadas de eliminar a las personas involucradas en actividades políticas a través de la desaparición, el asesinato y el encarcelamiento.
} 
arrimando datos a la flaca (una profesional del grupo) ahi, un trabajo en equipo hermoso. Hemos crecido mucho. Teníamos muchas cosas en común, sabíamos lo que queríamos y eso era lo más lindo. Teníamos bien claro porque estábamos ahí, por la gente, para trabajar por la gente para hacer una política verdadera" (entrevista a Felipe, Humahuaca, 1993).

Felipe, como miembro de la clase trabajadora, descubrió que los profesionales también son en definitiva trabajadores y que pueden compartir con "la gente", obreros como él, espacios de sus vidas. Así comenzó a participar de una red en la cual la obtención de títulos y cargos asocia simultáneamente el estudio al ingreso a un mercado de trabajo ligado a lealtades políticas e ideológicas y a la participación en partidos políticos. El está completamente comprometido con las actividades de la Iglesia y está convencido que la soberbia de clase, la explotación del trabajador y la violencia institucionalizada se pueden transformar a través de la cooperación laboral, de la actividad política y de la confrontación ideológica abierta. En todos los años que visité la región, tanto él como los profesionales eran aceptados por su disposición a acercarse a "la gente" y a llevarles servicios, pero también eran criticados por su excesivo énfasis en "lo material" y su falta de espiritualidad. A continuación vamos a explorar como ambas metáforas sobre las formas de articulación de las demandas, una que asocia a los humahuaqueños a través de las "ayudas" y "obligaciones" que ligan a los pobladores con las autoridades, y otra que los asocia a través de la "promoción humana" y la "confrontación política", operan en el ámbito de las organizaciones de base.

\section{Microemprendimientos y desocupación}

Durante las décadas en las cuales imperó una política de pleno empleo (1945-1970) la población indígena campesina se convirtió en parte activa de la clase trabajadora argentina. A través del salario accedieron a los servicios sociales a la vez que comenzaron a adquirir propiedades y a construir casas en las ciudades de la provincia para que sus hijos pudieran estudiar. Sin embargo, desde mediados de la década del ' 80 las políticas de privatización de las empresas del Estado (Ferrocarriles, Acerías, Dirección de Vialidad Nacional, Agua y Energía, Correos y Telecomunicaciones) y la reconversión tecnológica (ingenios y minas), así como una nue- va legislación laboral y social, produjeron transformaciones decisivas en la organización obrera y la satisfacción de sus demandas sociales.

Los despidos masivos ocurridos en la región llevaron a la población rural, habituada a migrar hacia los centros mineros y agroindustriales, a radicarse en la pequeña ciudad turística de Humahuaca. Esto fue recibido con júbilo por los funcionarios y comerciantes quienes vieron en el afluente de población, portadora de jugosas indemnizaciones por despidos, la emergencia de una nueva masa de votantes, de fuerza de trabajo y de consumidores. ${ }^{17} \mathrm{La}$ reacción mancomunada de las fuerzas locales fue la distribución inmediata de tierras libres de mejoras sobre las laderas de los cerros que rodean a la ciudad para que los migrantes desocupados construyeran sus viviendas. En las obras trabajaban la pareja y los hijos, y eventualmente recibían "ayudas" de vecinos. Dado que no todas las viviendas poseen instalación de agua, electricidad y cloacas, los vecinos comenzaron a reunirse para demandar el acceso a los servicios urbanos básicos.

En contraposición a los barrios del "centro", en los cuales las obras de infraestructura emprendidas son encaradas por personal rentado de la municipalidad y vistas como contribuciones a la "conservación del patrimonio histórico"; la infraestructura de los barrios nuevos estuvo a cargo de la "participación" de la gente misma. Frente a esta situación la Iglesia comenzó a desarrollar una tarea febril de concientización de las necesidades de los pobres y de promoción de sus derechos a la protección social, a la capacitación laboral y el acceso a una infraestructura urbana que garantice condiciones mínimas de confort. La asistencia a cursos y seminarios y la participación en organizaciones de base

17 Los humahuaqueños suelen repetir, "trabajo hay", pero ni los patrones privados ni el Estado están dispuestos a pagarlo. En 1993 el jornal de un peón rural ascendía a $\$ 10$ por ocho horas de trabajo. En 1993, ninguno de mis entrevistados trabajaba por menos de \$10, el almuerzo y la merienda. En 1995 el jornal continuaba fijo en $\$ 10$, pero ya no les daban ni almuerzo ni merienda, les extendían las jornadas de trabajo de ocho horas a 12 horas o suspendían los pagos. En 1997, los patrones decían que pagaban jornales de $\$ 7$, sin embargo, la gente no recibía más de $\$ 5$ por una jornada de 12 horas. Cabe destacar que desde 1992 el salario mínimo vital y móvil fue fijado en $\$ 200$ mensuales ( $\$ 10$ por día), mientras que el Instiluto Nacional de Estadística y Censos estima la "canasta familiar", es decir, los gastos mensuales de una familia nuclear, ascienden a $\$ 1.030$ mensuales. 
generaría "conciencia" sobre la situación de pobreza radical de los Coyas.

Desde 1992 Alicia y su esposo alimentaron la ilusión (ingenua como la ven ellos ahora) que la capacitación, la participación en grupos y la ejecución de los proyectos microempresariales propuestos por OCLADE les permitirian generar ingresos necesarios para construir la casa y derivar fondos para abrir una panadería o un restaurante modestos. Ellos habían llegado a Humahuaca en 1990, después de una infructuosa búsqueda de trabajo en la Mina el Aguilar y en la ciudad de Jujuy; tenían por ese entonces dos hijos pequeños.

En el año 1993. Alicia fue incorporada a las actividades del Equipo del Zonal de Humahuaca de OCLADE. ${ }^{18}$ Alicia, como el resto de los Animadores de la Promoción, circuló por barrios y por las localidades rurales promoviendo la conformación de grupos de vecinos que formularan proyectos relacionados a actividades de autoconstrucción de infraestructura urbana. Cuando en un barrio surgieron interesados, Alicia se encargaría de llenar los formularios para iniciar el trámite que desembocaría en el diagnóstico y la formulación definitiva de un proyecto.

Entre 1992 y 1997, Alicia participó de la formulación y ejecución de proyectos destinados a mejorar las viviendas del barrio, formó un grupo de mujeres microempresarias que criaron pollitos, formuló proyectos para la mejora de la infraestructura agrícola y ganadera de la localidad de Ronque y de construcción del salón y del comedor comunitario en el barrio de Santa Bárbara. Pese al carácter permanente de su colaboración con las actividades de promoción, solían excluirla de las discusiones sobre los proyectos, asimismo jamás recibió retribución monetaria alguna. Cuando le pregunté porqué impedían que participara de las discusiones, contestó que lo hacían porque ella era mujer, joven, y sobre todo porque no se dejaba manipular por los "jerarcas" de la institución. Cuando le pregunté porqué no le pagaban, contestó que para tener un cargo rentado en la Iglesia, había que "andar bien" con los "jerarcas". Asimismo su esposo Manuel aportó su "ayuda" para la mayor parte de los proyectos promovidos por Alicia. Como ninguna de estas actividades les permitió cumplir con su proyecto de transformarse en microempresarios gastronómicos y de terminar de construir la casa, Manuel comenzó a trabajar en la construcción de una escuela durante la campaña electoral y Alicia trabajaba como mucama en la casa de una familia de profesionales que trabajaban en dependencias estatales y en la ONG eclesial. Tanto Alicia como Manuel consideraban que a diferencia de sus progenitores que habían accedido al trabajo asalariado, durante esta década el trabajo asalariado era accesible solamente para un grupo reducido de pobladores y el resto tenía que arreglarse como podía para "progresar".

Para mostrarme lo generalizado de la situación, Manuel me llevó a conversar con vecinos y compañeros de trabajo que habían vivido experiencias similares. Pablo había venido de la mina El Aguilar con nueve hijos y una esposa. Con el dinero de la indemnización había alcanzado a construir parte de la casa, pero la hiperinflación le impidió comprar una camioneta para hacer "trabajos por su cuenta". Por esta razón se dedicaba a hacer changas ${ }^{19}$ en la construcción y su esposa trabajaba en el comedor o limpiando en casas particulares. Pero hasta el momento ninguno de los dos había tenido "suerte" porque, o bien, no les pagaban el salario, o bien les extendían la jornada laboral de modo tal que no se justificaba trabajar ni para las obras emprendidas por la provincia ni para un patrón particular.

Todos ellos se relacionaban con la Iglesia Católica y los partidos políticos con el fin de obtener jornales, comida y ropa para los chicos. Pablo y su esposa consideraban que la discusión entre "lo material" y "lo espiritual" era algo vacío. Ellos no distinguían entre lo "espiritual" y la "dádiva", por un lado, y "lo material" y "la promoción", por el otro. Ellos consideraba que los microemprendimientos, los comedores y la caridad eclesial eran "ayudas" y que, frente a la ausencia generalizada de fuentes trabajo, tanto la iglesia como las autoridades provinciales tenían la "obligación" de colaborar. Se veían enfrentados a una situación inesperada y utilizaban todos los caminos de los que disponían:

18 Conforme al informe de evaluación realizado por Misereor en el año 1992, OCLADE era una organización piramidal en la cual los sacerdotes tenían mucha influencia en las decisiones. Para democratizar el funcionamiento institucional y dar participación a otras voces, los evaluadores sugerían descentralizar la toma de desiciones en Equipos Zonales. Así se conformaron cuatro Equipos Zonales integrados por delegados de las localidades con autoridad para decidir que tipo de proyectos se iban a promover.

19 Changas: trabajos eventuales en diversos rubros. 
"En la comunidad (Mina El Aguilar) que estábamos nosotros pensábamos que nunca nos iban a jubilar, ve, nunca pensamos que nos iba a pasar esto, qué va a hacer, ya hemos salido... como dicen a sufrir en la vida; uno no siempre va a vivir en la riqueza y bueno... que va hacer cuando uno quiere a su familia quiere a su hogar tiene que trabajar de una manera o de otra. Si me parece que así debe ser. la parroquia está trabajando con las abuelitas de 70 años por Cáritas u OCLADE ese grupo grande, y le ayudan a los que necesitan porque para eso están. Si veo a una persona totalmente mal, falta de economía, y si es una familia que no tiene trabajo y sufre... lo tienen que ayudar. Bah, no todo, pero algo le dan, por lo menos una bolsa de mercadería y si no puede hacer su casita, lo ayudan por medio de $O C L A D E$, alguna cosa dan y hay otras que no. La gente no se acerca, no habla para que la Iglesia cumpla con su obligación" (entrevista a Pablo, Humahuaca, 1995).

Martín había llegado de Buenos Aires donde la situación estaba "fea". Trabajo había y se pagaba mejor que en la provincia de Jujuy pero la vivienda, la comida y los viajes eran demasiado caros y las personas se veían obligadas a tener dos trabajos. Trabajaba con Manuel y con Pablo en la construcción de la escuela ligada a la distribución de jornales durante la campaña electoral y también contrabandeaba mercadería cuando viajaba. El consideraba que los problemas de empleo no se iban a solucionar con una política de microemprendimientos regulada por políticos y funcionarios corruptos, sino que la gente debía organizar una "comunidad aborigen" para trabajar para ellos en lugar de "trabajar para un patrón", sean ellos empresarios, políticos o sacerdotes.

"Se van para las grandes ciudades (los migrantes) y bueno pierden su identidad; queremos recuperar las tierras en forma comunitaria, ese es el planteamiento que tenemos nosotros que tenemos conciencia... conciencia de identidad. Tenemos conciencia de todo, pero no es así con la gente que perdió su identidad ... dice yo no soy coya, no soy indio, no soy indígena, no soy nada yo soy jujeño o argentino ... pero a la misma vez, por ejemplo, al tema religioso consciente o inconscientemente hacen las religiones como antigua milenaria de nuestro pasado. Por ejemplo, este mes, el mes de la Pachamama, nosotros, por ejemplo, hemos ofrendado a la tierra el $1^{\circ}$ de agosto, ahora estamos trabajando. Pero ahora se está tomando más este..., por ejemplo, como le puedo deci, este..., con más fuerza de nuevo la parte religiosa milenaria. Hasta los curas lo tomaron también, pero lo tomaron estratégicamente. Entonces, tenemos que tener mucho cuidado, tenemos que ver bien estratégico, para ver como separar las cosas, porque lo nuestro, por ejemplo, la parte religiosa milenaria es muy profundo, tiene otro sentido que los curas no entienden pero usan a la gente".

Claudia: ¿Cuál es el sentido y por qué usan a la gente?

Martín: Por ejemplo, nosotros el mismo hecho, la misma palabra está diciendo Pachamama porque muchas veces Pachamama dicen que es Mamá Tierra y Pachamama no es Madre Tierra, Pachamama es mucho más grande. Pachamama es universo, Pachamama es naturaleza, Pachamama es el cosmos. Para decir Madre Tierra tengo que decir Pachamama. Pacha es Tierra y Mama Madre Tierra y Pachamama es universo naturaleza. Entonces nosotros le decimos: yo soy Pachamama pero yo soy naturaleza, yo soy parte de la Tierra, yo soy parte del Sol. yo soy parte de la Luna, ¿no? El Sol, la Luna no son hermanos nuestros, son parte nuestro, el Sol es naturaleza, por ejemplo, el conquistador cuando viene aquí dice, el Sol es el Dios de estos nativos o de estos indios ¿no? O del Inca dice, y no es asi, porque ellos toman sus patrones culturales europeos para demostrar que aquí la gente es ignorante y decirle que no saben o que esto se hace así. Ellos no vienen a aprender, a preguntar como le pensamos nosotros y se someten, vienen a conquistar a someter a nuestra costumbre a la forma de ellos. Yo discuto mucho, yo les digo, pero ellos tienen sus gente, sus profesionales, sus políticos y no les interesa que piensan los de acá. Aquí es totalmente distinto, una cultura totalmente distinta entonces nosotros decimos, que tomamos como punto fundamental a la Pacha o a la Tierra, tomamos como punto fundamental porque decimos que también de la Tierra venimos y a ella volvemos, de ella venimos y a ella volvemos, entonces la Tierra nos brinda los alimentos, ¿no? El sol también nos da vida, pero como no podemos estar agradeciendo cosa por cosa, árbol por árbol y en todos lados, dando de comer ... todas esas cosas lo tomamos de la Tierra y se lo da, lo que la Tierra nos da nosotros lo devolvemos, entonces no se lo piden a la Tierra tampoco, a la Tierra se lo agradece, hay una equivocación 
como dicen los curas, no entienden, que se lo va pedir hay dame Pachamama, mentira no se hace. Milenariamente todo se agradecía porque la naturaleza te está dando, entonces te está dando en forma natural entonces, hay que agradecerlo pero no se trata de pedirlo, los curas no entienden y por eso yo digo que hay que tener cuidado porque confunden, porque le usan a la gente para hacer número" (entrevista a Martín, Humahuaca, 1995).

Martín tenía una actitud de crítica abierta frente a la Iglesia porque la consideraba una institución representativa de la conquista y la dominación cultural en la región. Rechazaba las visiones de los sacerdotes y de los profesionales que pretendían convertirse en los agentes religiosos autorizados respecto de las variantes sincréticas locales. En lugar de tener en cuenta los conceptos culturales locales sobre las relaciones de reciprocidad existentes entre el paisaje o Pacha y los seres humanos, fomentaban una política de la "petición" o de la "dádiva" muy ligada a las estrategias de reclutamiento de la Iglesia.

La "gente de trabajo" se acerca a participar de los microemprendimientos y los servicios ofrecidos desde la ONG eclesial o se acerca a la Casa de Caridad con la perspectiva de iniciar actividades económicas, de mejorar la infraestructura del barrio y de recibir asistencia social. ${ }^{20}$ Ya sea que se trate de personas que vienen de trayectorias laborales estables o de personas que nunca tuvieron un trabajo estable, quienes participan de las experiencias de organización vecinal de base ven ambas ofertas como la posibilidad socialmente aceptada de obtener bienes y servicios que permiten reproducir la vida. La Iglesia propone romper con los lazos de asimetría que caracterizaron las relaciones de los indígenas pobres con la sociedad. Sin embargo, sus dirigentes no pertenecen a los estratos empobrecidos de la clase trabajadora local, por el contrario, pertenecen a los estratos que han logrado sostener sus empleos estables y niveles de consumo aceptables que eventualmente utilizan a la Iglesia como un lugar de reclutamiento de mano de obra para sus propios emprendimientos y de adhesiones ideológicas necesarias para llevar adelante sus propias carreras políticas y profesionales.

\section{Participación en los partidos políticos}

La generación de grupos y organizaciones de base católicas en Humahuaca no está por fuera ni es in- dependiente de las clientelas y de las convenciones sociales que las rigen. Por el contrario, la gente que dicta y toma cursos de capacitación y que participa de los proyectos eclesiales está completamente integrada a las actividades de los partidos políticos. La participación en organizaciones de base católicas es sólo una parte de una totalidad que la excede. Los sacerdotes son perfectamente conscientes de esta cuestión y, frente a cada elección, publican críticas sobre los políticos y las actividades partidarias, destinadas a utilizar la experiencia y las relaciones de los animadores para apoyar proyectos electorales. Desde la perspectiva de los sacerdotes, la actividad política partidaria también lleva a la alienación, dado que en lugar de basarse en la promoción de los derechos, promueven carreras profesionales y el tráfico de influencias.

En una oportunidad Alicia volvía de un encuentro de animadores y comentaba indignada que, el Hermano Sandro les había dicho que si ellos colaboraban con las máquinas electorales eran personas "indignas", aludiendo a que entregar el voto por comida o por un jornal no se correspondía con una conciencia sobre los derechos del ciudadano. Como muchos vecinos, ella consideraba que ese tipo de apreciaciones sólo era posible en quienes tienen un empleo con perspectivas y no tienen que salir a buscar trabajo diariamente para garantizar la reproducción de sus hogares. Por otra parte, colaborar en una campaña no garantizaba el voto a ningún candidato. Simplemente "aprovechaban" la posibilidad de obtener un jornal o mercaderías y luego votaban por uno u otro candidato, ya que, por otra parte, no existían diferencias visibles entre uno y otro. Asimismo, no consideraban que su participación en los grupos de base propuestos por la Iglesia, hubiera producido efectos diferentes. Sus hijos asistían al comedor y ellos dependían de los proyectos y de las necesidades de mano de obra de OCLADE, de la Municipalidad y de los profesionales para construir sus casas y acercar jornales. Después de todo, el tipo de organizaciones y de proyectos de vida propuestos por sacerdotes era similar, y esto era visible en el hecho de que los sacerdotes y los profesionales que trabajaban para la $\mathrm{ONG}$ eran ellos mismos candidatos ofuncionarios políticos, y apoyaban candidaturas públicamente.

20 A través de la ONG se canalizaron fondos destinados a implantar comedores barriales destinados a niños, a mujeres embarazadas y a ancianos. 
Los vecinos que participaban en las organizaciones de base incorporaban las actividades partidarias al resto de sus actividades cotidianas destinadas a obtener jornales, proyectos y a reclamar por sus derechos. Invitaban a todos los candidatos a los salones comunitarios para escuchar sus propuestas, criticarlos y sugerir cambios en la política económica. En reuniones que duraban varias horas, los candidatos presentaban sus diagnósticos de la situación y hacían propuestas algo vagas sobre, por ejemplo, cómo iban a disminuir el desempleo, visto como el principal problema local. ${ }^{21}$ Una vez finalizada la exposición de los candidatos, los vecinos critican la gestión del partido en el gobierno y la del propio candidato si ya actuó en la función pública; hacen una lista de demandas: empleo, inf raestructura de salud y educativa adecuada. entrega de títulos de propiedad, mayor agilidad en los trámites; finalmente, reclaman la asistencia inmediata con materiales de construcción, jornales, alimentos e insisten en que tienen la convicción de que las demandas no serán atendidas por la distancia existente entre las promesas de bienestar de los sucesivos gobiernos y la privación material en la que viven desde comienzos de esta década:

"los políticos hablan lindo: en época de elecciones, prometen que van a traer trabajo y dicen 'vení hermanito participá con nosotros', pero después se olvidan" (Comedor Comunitario del Barrio de Santa Bárbara, Humahuaca, 1995).

Los habitantes de los barrios saben perfectamente que Humahuaca es una intendencia que sólo interesa a los profesionales de la política como plataforma de lanzamiento a candidaturas provinciales y nacionales, pero que el bienestar de los pobladores de la ciudad o de la región no les interesa. En una oportunidad, después de varios días de escuchar discursos electorales por parte de candidatos pertenecientes a diversos partidos, un grupo de animadores ancianos que "no creían" en los políticos salieron del salón para discutir las propuestas y decidir sus votos. En medio de la discusión comenzaron a "tirar la coca" (hojas de coca) para preguntarle si cada candidato cumpliría o no con sus promesas de trabajar para la población de la región. Eligieron tres hojas de coca, las colocaron entre las manos, las soplaron y las tiraron sobre el suelo. Este procedimiento fue realizado tres veces para cada candidato. Los vecinos comentaron que conforme a su lectura de la coca, el candidato Medina era el favorito, pero que seguramente no cumpliría con el programa establecido. Para ganar su adhesión, una campaña no bastaba, sino que debía cumplir con ellos durante tres mandatos consecutivos. Finalmente, la gente habla continuamente de política y atribuye el desempleo y el deterioro de sus condiciones de vida al descontrol inflacionario que caracterizó al gobierno de los radicales y a la política de privatizaciones, a la desindustrialización y a la corrupción impulsada por la corriente menemista del partido justicialista actualmente en el gobierno.

Como hemos señalado, los miembros de las organizaciones de base no conforman un grupo políticamente homogéneo que decide su voto ligándolo a una persona a la que siguen ciegamente o al momento concreto en el que participan de la máquina partidaria. Por el contrario, la decisión de votar está ligada a escuchar las propuestas de cada partido y candidato, a evaluarlas y a discutirlas con los vecinos, los familiares y a criticar fuertemente a los candidatos por la desconexión existente entre discursos electorales y representación de la clase trabajadora, indígena o no-indígena. En el nivel local, la gente utiliza la infraestructura barrial que construyó para reunirse con los candidatos y comprometerlos a traer mejoras para los vecinos del barrio. Saben perfectamente que en un sistema de democracia representativa, la representación de los intereses de los ciudadanos está mediada por carreras profesionales, por la corrupción administrativa, el tráfico de influencias y por alianzas de intereses entre políticos y empresarios. Utilizan las elecciones para reactivar sus demandas de respeto por su derecho al trabajo, a la propiedad, a la educación y a la salud. En el nivel nacional, el recuerdo de la experiencia de hiperinflación de finales de los ' 80 y comienzos de los '90 llevó a los pobladores a votar por Menem quien garantizó la estabilidad de los precios.

La independencia del voto de la máquina electoral se ve reflejada además en dos cuestiones: En primer lugar, la gente vota partidos diferentes para el nivel municipal, provincial y nacional y para las legislaturas municipales, provinciales y el congreso de la nación; en segundo lugar, la independencia de

21 Desde 1993 los candidatos afirman una y otra vez la llegada de inversiones destinadas a fomentar microemprendimicntos, actividades comerciales destinadas al turismo y la posibilidad de declarar a la región zona-franca. Estas actividades deberían contribuir a generar nuevos puestos de trabajo. 
las decisiones sobre el voto de la máquina partidaria puede comprobarse en el hecho de que las elecciones están ligadas a refinados mecanismos de fraude electoral promovido por los partidos mayoritarios, como "el voto encadenado".

Además, es habitual escuchar entre los candidatos ancianos que ya las cosas no son como antes. Las estructuras partidarias no son tampoco un bloque homogéneo como en otras épocas cuando no había elecciones internas en los partidos y los candidatos eran designados por "cúpulas", "consejos" y "comandos superiores". Es interesante destacar que nadie recuerda los nombres de los políticos, ni se interesa por sus biografías, sino que recuerdan a las "almas benditas" de Perón y de Guzmán. Políticos provinciales altamente estimados por las clases medias, como Martiarena y Snopeck, no son recordados como "almas benditas". sino que son personas a quienes la gente olvida, y sólo recuerda cuando comentan estafas o abusos. En contraposición a ellos Perón y Guzmán son recordados, no por sus vidas ejemplares, sino porque sus políticas estaban basadas en la ampliación de los derechos y en la inclusión de los trabajadores a los "beneficios". Localmente, el concepto de "beneficio" es asociado a la industrialización que trajo aparejada el salario regulado y un conjunto de servicios sociales, y no al hecho de contar con un "benefactor". En este sentido, la gente con sus prácticas y pensamientos cuestiona vínculos basados en un liderazgo "populista", $\tan$ habituales en el pensamiento de los miembros de las clases medias. En la actualidad, las estructuras partidarias están completamente fragmentadas y cada partido presenta varios candidatos para un cargo. En la práctica son los candidatos de un partido los que compiten entre sí por el voto de los ciudadanos.

\section{Participación en movimientos de protesta}

En relación a la participación en movimientos de protesta, los habitantes de Humahuaca recordaban "El Aguilarazo" como hito de la memoria colectiva. En el año 1973, los mineros habían realizado una protesta porque no les otorgaban los aumentos pactados por la Confederación General de Trabajo. Como la empresa se resistía a incorporar los aumentos, los mineros hicieron una huelga que terminó en un levantamiento generalizado reclamando el cumplimiento de la ley. La siguiente escena ilustra lo que se liberó durante la huelga: “...bueno esa vez de la huelga era porque no le aumentaban el sueldo a la gente. La gente necesitaba que le aumenten el sueldo pero no quisieron aumentar entonces hicieron huelga. Al jefe superior lo han traído urgente, le han llevado a latigazos del Molino (zona baja donde se ubican las oficinas) a la Veta (lugar alto donde se encuentra la entrada a la mina). En Veta también habia oficinas y ahi se escondió, se hizo la embarazada; bueno, la gente se ha enterao y lo han sacado a latigazos hacia la Veta".

Claudia: ¿Al jefe? ¿Cómo embarazado. los hombres se embarazan?

"No por eso. El se habia hecho el embarazado. Si fue, así comentaba la gente, no sé, si es cierto o es mentira. Yo, tonta, tenía miedo. Uh, a mí también me van a matar, a disparar, pero mentira no era así, era al jefe de la mina... y después se han ido quemando las oficinas, los camiones, las camionetas haciendo daño la gente, quemando los hoteles, las casas a los dueños de la mina. Más tarde a las 6 ó 7 he salido a caminar hacia las orillas con todos los autos quemados, las casas han encontrado al jefe, al más capo de la compañía, los han llevado a latigazos a pié, a la veta, a la punta del cerro, 'así sufrimos nosotros, asi trabaja mi marido, asi vos también me la vas a pagar', así comentaba la gente. así le han hecho sufrir a él, le han hecho sufrir pero peor ha sido para nosotros, a los obreros porque nos han castigado peor..." (entrevista a María, Humahuaca, 1995).

En las conversaciones habituales este acontecimiento no constituye una batalla ganada en un camino de lucha cuyo destino es la implantación del socialismo, sino que constituye una inversión de la situación de dominación a la cual ellos se ven sometidos cotidianamente. La apelación a la metáfora del "embarazo" en asociación al miedo del jefe es la forma en la cual la clase obrera indígena experimenta sus relaciones con la patronal. La situación de dominación supone la feminización del otro a través de su sometimiento forzado representado en la utilización del látigo. El látigo no era un instrumento usado en la mina, pero fue el instrumento habitualmente utilizado por los antiguos hacendados o terratenientes, los administradores de las empresas azucareras y por los capataces de los cañaverales para transformar a los indígenas en arrenderos y en obreros. De esta forma, la clase trabajadora indígena intentó de una vez mostrarle a los patrones de qué se trata ser 
minero en el Noroeste argentino: látigo, abuso y sufrimiento. Pablo y don Agustín solían referir al "Aguilarazo" como un acontecimiento histórico aglutinante de "todos los trabajadores".

En cuanto a la participación en protestas recientes, en el año 1997 se produjeron en todo el país "cortes de ruta" acompañados de movilizaciones contra las políticas de privatización y el desempleo que estas habían desatado en las provincias. En este contexto, un conjunto de vecinos de la ciudad de Humahuaca decidieron plegarse a las protestas y detuvieron el tráfico de bienes y personas en la Ruta Nacional $\mathrm{N}^{\circ} 9$ que conecta la frontera norte del país con la capital provincial San Salvador y con la capital federal. Los manifestantes demandaban la prolongación de los contratos laborales y la implementación de nuevos programas de trabajo. Luego de cinco días de protesta el corte de ruta de Humahuaca fue levantado porque las autoridades provinciales garantizaron la continuidad y ampliación de los programas. Ninguno de mis vecinos despedidos de la mina El Aguilar estuvo constantemente reunido y participando de la protesta, sino que se acercaban esporádicamente para comentar la situación y "hacer número". Los cortes de ruta fueron producidos por personal contratado de la Municipalidad, representantes sindicales, comerciantes, personal de la Iglesia y empresarios locales que se sumaron a una ola de protestas nacionales. Mientras caminaba hacia la ruta me detenía en las casas y preguntaba a los vecinos si querían acompañarme, pero ellos se disculpaban amablemente diciendo que estaban "ocupados", es decir, trabajando en la construcción de sus casas, cocinando, lavando, haciendo "changas", trabajos por el día que les reportaban ingresos. Consideraban que era justo que quienes participaban de los planes de trabajo protestaran para defender las fuentes de trabajo, pero dado que ellos no tenían trabajo, ni organizaciones que representen sus intereses, daban continuidad a sus actividades cotidianas.

En la ciudad de Humahuaca quienes participan de protestas y toman contacto con agentes que tienen injerencia en los niveles de decisión política son inmediatamente incluidos en las dinámicas institucionales que no están ligadas ni a la mutualidad, ni al ejercicio de los derechos, sino a un sistema político basado en la obtención de cargos. En este sentido, las diferencias en la intensidad de la participación en las protestas callejeras pueden ser leídas como una forma abierta de mostrar la ruptura existente entre los miembros de los hogares que dependen de puestos de trabajo estables para su reproducción y que forman parte de organizaciones sindicales y políticas, y quienes no cuentan con ello. Durante los días que duró la protesta, los gendarmes de Humahuaca comenzaron a salir de sus puestos y a pasearse armados por la ciudad. Estas actividades contribuyeron a generar un clima de tensión y la pregunta sobre hasta qué punto valía la pena involucrarse frente a la posibilidad de una escalada de violencia, aún cuando el reclamo era considerado justo por el conjunto de la población.

\section{Conclusiones}

Burdick (1993: 218) en su trabajo sobre las comunidades eclesiales de base en Brasil, se refiere al hecho de que los grupos campesinos rechazan la confrontación ideológica abierta que caracteriza a la negociación sindical. En Argentina, la emergencia del movimiento obrero organizado en sindicatos articulados en partidos políticos, fundamentalmente el peronismo y el justicialismo, representativos de los intereses de los trabajadores, llevaron a que las reivindicaciones de los trabajadores fueran planteadas no como parte de una confrontación ideológica abierta entre los trabajadores y los empresarios, sino como parte de una negociación entre corporaciones mediada por el Estado (James 1990: 2934). En este sentido, el análisis de James respecto del carácter reformista del peronismo, pone de manifiesto que quienes participaron de movilizaciones obreras no cuestionaron el orden social vigente, pero sí el modelo de ciudadanía política basado en el voto universal que, sin embargo, excluía los reclamos de distribución económica de las clases trabajadoras y del ejercicio de su derecho a asociarse y a conformar sindicatos libremente, así como de formar partidos políticos independientes. En este sentido, el período 1973-1976 resulto paradigmático respecto de un movimiento sindical activo y contestatario en el cual se enmarca "el Aguilarazo". Justamente el activismo sindical de base fue lo que la dictadura militar de 1976-1983 vino a reprimir y a exterminar, así como al conjunto de instituciones y al cuerpo legal que lo sustentaba (Romero 1994: 287 y 288, Martucelli y Svampa 1997: 33 y 34).

En la última década, el gobierno justicialista y el sindicalismo, tradicionalmente peronista, convivieron pacíficamente en un contexto de acuerdos so- 
bre ajustes presupuestarios, privatizaciones de empresas estatales, reforma del Estado y creciente flexibilidad laboral. Sin embargo, en la provincia de Jujuy surgió un liderazgo clasista de base, vinculado a los gremios estatales, que cuestionó tanto las políticas provinciales como nacionales de ajuste, privatización y reforma. El "corte de ruta" de Humahuaca no se relaciona con manifestaciones espontáneas sino con el activismo sindical basista, dado que quienes participaron del "corte", aún cuando recibieron la adhesión de los vecinos recientemente expulsados del mercado laboral, era el personal contratado por la administración pública provincial. El activismo sindical basista contribuyó a reforzar las reivindicaciones y las manifestaciones de oposición abierta al modelo económico implementado en los años de 1990.

Recién en los últimos meses de gobierno radical, la Confederación General del Trabajo emerge como fuerza confrontacional y opositora (y visiblemente oportunista) frente a medidas gubernamentales consideradas antipopulares, como los ajustes presupuestarios, los despidos de empleados estatales y la nueva legislación laboral que afectan tanto a los empleados estatales como a quienes dependen de planes sociales para su subsistencia. En este sentido, las organizaciones no gubernamentales que reciben financiamiento del Estado para llevar adelante sus proyectos de intervención social, se han visto afectadas tanto por los sucesivos ajustes, como por la corrupción y el clientelismo que caracterizaron al gobierno anterior y la insensibilidad social y la improvisación que define la actual gestión gubernamental.

Desde el punto de vista de los pobladores locales, las pretensiones de la Iglesia Católica local de representar la conciencia y la "voz de los más pobres" no resultan convincentes. La Iglesia Católica tradicionalmente reclutó a sus líderes en la población con mayores niveles educativos, cargos estables y disponibilidad de tiempo que les permitirán compatibilizar el trabajo con las labores desarrolladas en la iglesia. Por lo tanto, la clientela clásica de la Iglesia Católica, no buscaba en la participación religiosa una solución a sus problemas económicos, sino una plataforma que les permitiera gestionar recursos adicionales.

Nuestra pregunta inicial de por qué los pobladores reclaman una iglesia dedicada a "lo espiritual" y critican el énfasis de los sacerdotes en la promoción de las "necesidades materiales" de los pobres, se relaciona con lo siguiente: en la actualidad, la participación en la ONG eclesial resuelve las necesidades materiales de aquellas personas que por su mayor nivel educativo formal, por el control de puestos y de relaciones consiguen articular sus actividades en el Estado con las actividades de esa ONG. De este modo, trabajar en una ONG supone para los profesionales la posibilidad de generar ingresos adicionales que les permiten sostener niveles de consumo aceptables en condiciones de ajuste permanente. Estos profesionales están en conflicto permanente con los líderes tradicionales de la Iglesia, quienes no reciben remuneración alguna por las tareas que desempeñan.

Las prácticas religiosas locales, como las celebraciones a las "almas" o a la Pachamama, no están asociadas ni al reclutamiento espiritual, ni a la educación formal, ni la obtención de un puesto estatal. La socialización en un medio agrícola y pastoril, el trabajo asalariado temporario, la urbanización y el respeto por las producciones simbólicas de los antepasados constituyen las prácticas que asocian la identidad de clase con la identidad étnica, basadas ambas en el trabajo temporario en la agricultura, en la industria y en la construcción, en la migración y en el respeto por las costumbres de "estilo". La identidad de clase y la identidad étnica forjadas en el trabajo campesino y obrero coexisten en tensión con una identidad y unas prácticas de clase identificadas con la educación, el empleo público, el consumo y la urbanización. Esto explica las tensiones confrontacionales existentes entre quienes se identifican a sí mismos como la "gente del campo" o "los trabajadores" frente a quienes se identifican como "gente de la ciudad" o "los profesionales" y/ o "los patrones".

Un liderazgo basado en altos niveles educativos, en el control de puestos estatales y en el trabajo indígena no-remunerado, en lugar de generar imágenes de ruptura respecto de las clases patronales o los que "más tienen" genera continuidades con expectativas de ascenso social a través del empleo público. En este contexto, las críticas explícitas al énfasis de los sacerdotes en "lo material" y al "individualismo" de los promotores, se relacionan al reconocimiento que el paso de "condiciones de vida menos humanas a condiciones de vida más humanas" propuesta por los sacerdotes, tiene que ver con 
la educación escolar y con el control de cargos estatales, es decir, con los canales característicos del ascenso social en la Argentina.

En el contexto urbano los migrantes tampoco conforman un grupo indiferenciado. Por un lado, el liderazgo asociado al sistema de títulos y cargos vuelve a ocultar la desvalorización de los conocimientos religiosos y las desigualdades que las diferencias culturales generan entre los católicos "profesionales" y con "estatus" de la ciudad, y el catolicismo "espiritualista" de "la gente". Por otro lado, el hecho de tener que salir a buscar trabajo diariamente para subsistir se superpone con las demandas eclesiales de participar en manifestaciones públicas, en actividades de capacitación, organización de grupos vecinales y con el trabajo en emprendimientos comunitarios. Asimismo, las discusiones y enfrentamientos permanentes entre los partidarios de una política eclesial basada en la satisfacción de las necesidades materiales, la crítica a la mendicidad y a la asistencia frente a la existencia adivinos y teólogos populares muestra nuevamente las diferencias existentes entre los católicos.

Pese al interés de los sacerdotes por diferenciarse de las prácticas y de los mensajes religiosos propagados por el catolicismo colonial y el catolicismo preconciliar, las continuidades son muy fuertes. $\mathbf{L a}$ democratización religiosa supuso la conformación de una nueva dirigencia católica que comenzó a integrar gente con bajos niveles educativos, de piel oscura que vivían en el campo y que anteriormente eran excluidos por la Iglesia. La gente reconoce que la incorporación de los animadores, la catequesis y la participación en los movimientos de jóvenes y de mujeres ha permitido perder el "miedo" frente al "padrecito"; generar relaciones de amistad entre los miembros; acceder a cargos rentados en la Iglesia y en el Estado; contar con una Iglesia o un salón comunitario en su localidad y con una visita sacerdotal mensual; tener títulos que los autorizan y prestigian frente a los sacerdotes y a los vecinos; y que han dejado de sentir temor frente a los profesionales.

Pese a ello los sacerdotes y los profesionales continúan siendo personas distantes que viven en casas confortables en el centro de los pueblos; poseen vehículos; tienen acceso a las universidades y hacen viajes por el país y por el mundo. Cuando salen al campo cuentan con cuartos, comidas, bebidas y atenciones especiales que marcan jerarquías frente al resto de la feligresía. Los sacerdotes y los profesionales imponen horarios, temas, actividades, cobran dinero por los servicios que prestan y sobre todo imponen significados y valoraciones morales conforme a los parámetros que rigen sus estilos de vida. Su participación en la escena política pública y su alto perfil mediático los acerca al poder. Estas prácticas institucionalizadas marcan diferencias en las formas de concebir y de experimentar la participación que dan lugar a la emergencia de diferencias sociales básicas. Si a ello le sumamos el énfasis en la ignorancia, la pobreza y en la marginalidad de los coyas en lugar de producir rupturas o inversiones respecto de las formas en las cuáles se conciben las diferencias que son la base de la oposición y de la confrontación social, los sacerdotes tienden a negarlas.

\section{BIBLIOGRAFIA}

BURDICK. J., 1993. Looking for God in Brasil. The University of California Press.

COMAROFF, J. y J. COMAROFF, 1992. Etnography and the historical imagination. Westview Press, Colorado y Oxford.

DE LA FUENTE, A., 1999. Gauchos, Montoneros y Monteneras. En Goldmann, Noemi y Salvatore, Ricardo (comp.) Caudillosmos Rioplatenses. Nuevas Miradas a un viejo Problema. Eudeba, Facultad de Fìlosofía y Letras, Universidad de Buenos Aires: 267-294

GOLdMANN, N. y R. SALVATORE, 1998. (comp.). Caudillosmos Rioplatenses. Nuevas Miradas a un viejo Problema. Eudeba. Facultad de Filosofía y Letras, Universidad de Buenos Aires.
HARRIS, O. y T. BOUYSSE-CASSAGNE, 1988. Pacha: en torno al pensamiento Aymara. En Albó, Javier (comp.) Raíces de América. El mundo Aymara. Alianza Editorial, Madrid: 217-283.

HARVEY, P, 1997. Die Geschlechtliche Konstitution von Gewalt. Eine vergleichende Studie über Geschlecht und Gewalt. Soziologie der Gewalt. Westdeuscher Verlag GmbH. Opladen/Wiesbaden.

ISLA, A. 1992. Dos regiones, un origen. Entre el silencio y la furia. En Sociedad y articulación en las Tierras Altas jujeñas. Crisis terminal de un modelo de desarrollo. A. Isla (Ed.), MLAL, UBA, Buenos Aires. 
JAMES, D., 1990. Resistencia e Integración. Sudamericana, Buenos Aires, 1990.

---- 1997. Gendered worlds of Latin American women workers. From households and factory to the union hall and ballot box. Duke University Press, Durham, London.

LOZANO, C., 1999a. Misiones cristianas y Población con raíces indigenas: Un debate sobre la identidad y sobre las diferencias sociales en el Noroeste Argentino. Tesis de Doctorado, Berlín.

MARTUCELLI, D. y M. SVAMPA, 1997. La Plaza Vacia. Las transformaciones del peronismo. Losada, Buenos Aires.

MURMIS, M. y S. FELDMAN, 1996. De seguir así. En Beccaria, Luis y López, Néstor (comps.) Sin trabajo. Losada/UNICEF, Buenos Aires: 197-198.

NASH, J., 1985. Religión, Rebelión y Conciencia de Clase en las Comunidades Mineras del Estaño en Bolivia. Allpanchis, Nr. 26, Año XV, Vol. XXII. Instituto de Pastoral Andina, Cuzco, Perú: 115-149.

PLATT, T., 1988. Conciencia andina y conciencia proletaria. Qhuyaruna y Ayllu en el norte de Potosí. Revista Latinoa- mericana de Historia Económica y Social. № 2: 47-73, Instituto de Estudios Peruanos, Lima.

PAZ, G., 1998. Liderazgos étnicos, caudillismos y resistencia campesina en el norte argentino a mediados del siglo XIX En Goldmann, Noemi y Salvatore, Ricardo (Comp.) Caudillosmos Rioplatenses. Nuevas Miradas a un viejo Problema. Eudeba, Facultad de Filosofía y Letras, Universidad de Buenos Aires, pp. 267-294.

ROMERO, L. A., 1994. Breve historia contemporánea de la Argentina. Fondo de Cultura Económica, Buenos Aires.

RUTLEDGE, I., 1987. Cambio Agrario e Integración. El desarrollo del Capitalismo en Jujuy. Proyecto Ecira. Facultad de Filosofía y Letras, UBA/MLAL, CICSO, Buenos Aires.

\section{Fuentes:}

Clarín: 13.05.2000: 1, 3-14.

La Nación: 13.05.2000: 1, 5-9

La Nación: 14.05.2000: 1, 12-15 y 21 .

Revista Animadores, 1995. Nr.176:1.

Revista Animadores, 1995. NI. 184:8.

INDEC, 1994: Censo 91, Jujuy, Serie B Nr. 10. 1994:61.

INDEC, 1994: Censo, 1991:45, 49, 54 